\title{
Water Quality Assessment of Sirsiya River
}

\author{
Binod P. Shah ${ }^{1}$ and Bhoj R. Pant ${ }^{2}$ \\ ${ }^{1}$ Himalayan Alliance for Climate Change (HIMCCA) \\ Kathmandu, Nepal \\ ${ }^{2}$ Nepal Academy of Science and Technology (NAST) \\ Khumaltar, Lalitpur, Nepal \\ E-mail:binod725@gmail.com
}

\begin{abstract}
The parameters such as temperature, PH, TSS, TDS, ammonia, phenol, cyanide, sulfide, oil and grease, chloride, DO, COD and BOD were taken to assess the water quality of Sirsiya river, central southern Nepal. Water samples were collected from upstream to downstream from the point receiving industrial effluent to Sirsiya river. It receives wastewater burden of more than 250 industries along Bara/Parsa industrial corridor. All the parameters except oil and grease were found within the generic standard. The study revealed that the physic-chemical characteristic of the river water was changing as a result of the discharge of untreated effluents from different industries. This may impact on water quality of Sirsiya river and also pose human health problems.
\end{abstract}

Key words: effluents, effects, industry, oil and grease, urbanization

\section{Introduction}

The scarcity of clean water and pollution of water bodies has led to a situation in which people are forced to use the polluted water in their agricultural field and even they drink after minor cloth filtration. Such activities can be seen on the banks of Bishnumati and Bagmati in Kathmandu valley and similar activities exist on the banks of Sirsiya river in the central southern Nepal. If the wastewaters containing industrial effluents are used as irrigation water, chemical pollutants such as heavy metals can accumulate in the soil and crops and thereby pose human health hazards. The wastewater for irrigation possess pathogenic enteric microorganisms, i.e., bacteria, viruses, and parasites. These pathogens can pose health risks for the farmers and communities who are exposed to the wastewater, and for the consumers of produce irrigated with wastewater. The main health risk in relation to wastewater irrigation is an infection with intestinal helminthes (Mara \& Cairncross 1989). These health risks can be greatly reduced by treating the wastewater before using it.

There are low-cost treatment technologies suitable for Nepal such as wastewater stabilization ponds, which are used extensively in mid-income countries. The objective of the study was to estimate the water quality of Sirsiya river with respect to industrial pollution.

\section{Methodology \\ Study area}

The study sites are Birgunj and surrounding area of Parsa district that have direct connection with Sirsiya river. It is the centre of industrial hub and known as Bara/Parsa industrial corridor. The government of Nepal has declared this area as Special Economic Zone (SEZ). There are more than 250 industrial buildups in this corridor and all the industrial wastewaters from there is directly/indirectly discharged into Sirsiya river. It is located at approximate latitude of $27^{\circ} 18 \mathrm{~N}$ and longitude $84^{\circ} \mathrm{E}$ at about $130 \mathrm{~m}$ above mean sea level.

\section{Sampling}

Water samples were collected from upstream $\left(\mathrm{S}_{1}\right)$, midstream $\left(\mathrm{S}_{2}\right)$ and downstream $\left(\mathrm{S}_{3}\right)$ from the point where effluent is discharged into Sirsiya river. Samples were collected in glass bottles by the end of November 2011. Before sampling, the sample bottles were rinsed three times with river water and then the samples were collected. The sampling was done by dipping each sample bottle at approximately $10-20 \mathrm{~cm}$ below the 
water surface, projecting the mouth of the container against the flow direction. The samples were transported within $24 \mathrm{hr}$ to the Water Engineering and Training Center (WETC) at Kathmandu for analysis.

\section{Physicochemical analysis}

The samples were analyzed for total suspended solids, total dissolved solids, ammonia, phenol, cyanide, sulfide, oil and grease, chloride, dissolved oxygen, chemical oxygen demand and biological oxygen demand using standard methods for analysis of water and wastewater (APHA 2008). The physical parameters (temperature and $\mathrm{PH}$ ) were measured onsite using a multiparameter ion specific meter (Hanna WTW 304 I). The total suspended solid was estimated suing gravimetric method. Chemical parameters estimated for the determination of ammonia, phenol and cyanide were measured by UV spectrophotometer (JENWAY 6505UV/VIS). Sulfide was determined iodometrically.

\section{Results and Discussion}

A total of three samples were collected from upstream, midstream and downstream to effluent discharged point at Sirsiya river. The reason to choose these three sites was to estimate the pollution level before and after the mixing of effluent in Sirsiya river. The result of this work shows that physical parameters estimated for $\mathrm{PH}$, temperature, TSS, TDS were measured within the generic standard (Table 1).

The $\mathrm{pH}$ of the wastewater ranged between 6.5-6.9. These values are within the tolerance limit of wastewaters discharged into surface water (WHO 2004). The EU also has guidelines for the $\mathrm{PH}$ of industrial effluent to discharge into inland surface water (Chapman 1996).
The temperature varied in different seasons and locations. During the study, temperature was recorded 18.6, 22.4 and $17.6^{\circ} \mathrm{C}$ for upstream, midstream and downstream, respectively. These values are within the generic standard of $40^{\circ} \mathrm{C}$ recommended for the wastewater discharged into surface waters. The effluent temperature $<40^{\circ} \mathrm{C}$ does not appear to pose any threat to aquatic cycle and homeostatic balance of water bodies (Jaji et al. 2007).

Total suspended solids (TSS) ranged between $<1$ - 54 $\mathrm{mg} / \mathrm{l}$. It was found within generic standard and national standard recommended by the Nepal Government. Somnath (2003) reported that larger solid particulate matter remains suspended as a result of charges on the surface of small particles in the effluent.

Total dissolved solid (TDS) was found from 218 to 488 $\mathrm{mg} / \mathrm{l}$. It was mainly due to carbonates, bicarbonates, chlorides, sulphates, phosphates, nitrates, nitrogen, calcium, sodium, potassium and iron (Kannan et al.2009). The TDS negatively influence the quality of surface and also toxic to aquatic lives by causing osmotic stress and affecting the osmoregulatory capability of the organisms (McCulloch et al. 1993). In tanning process, protein, hair, skin and emulsified fats are removed from the hides, which are released in the effluent and therefore increase the total solids.

Ammonia in wastewater ranged between 2.84 to $6.6 \mathrm{mg} / \mathrm{l}$ (Table 2). This value is within the standard and do not pose any threat to aquatic ecosystems. The low concentration of ammonia was due to dilution of river water from its tributaries. Ammonia (NH4-N)

Table 1. Physical quality of water

\begin{tabular}{|c|c|c|c|c|}
\hline \multirow[t]{2}{*}{ Parameters } & \multirow{2}{*}{$\begin{array}{c}\text { Generic Standard } \\
\qquad 5.5-9.0\end{array}$} & \multicolumn{3}{|c|}{ Sampling Sites } \\
\hline & & $\begin{array}{c}\text { Upstream } \\
6.6\end{array}$ & $\begin{array}{r}\text { Midstream } \\
6.8\end{array}$ & $\begin{array}{r}\text { Downstream } \\
6.9\end{array}$ \\
\hline Temperature $\left({ }^{\circ} \mathrm{C}\right)$ & 40.0 & 18.6 & 22.4 & 17.6 \\
\hline TSS(mg/l) & $30-200$ & $<1.0$ & 28.0 & 54.0 \\
\hline TDS(mg/l) & NA & 218.0 & 348.0 & 488.0 \\
\hline
\end{tabular}

NA - Not available

occurs in water bodies due to the breakdown of nitrogenous organic and inorganic matters $\left(\mathrm{NO}_{3}+\right.$, $\mathrm{NO}_{3}+$ and molecular $\mathrm{N}_{2}$ ) present in soil and water. Other sources of ammonia in wastewater are industrial discharged and generated solid waste. Chemical fertilizer used in the cultivated field also contributes $\mathrm{NH}_{4}-\mathrm{N}$ to surface water.

The phenol ranged between less than 0.04 to $0.64 \mathrm{mg} /$ l. These are biocides and toxic to fish because of high oxygen demand of the compounds. Concentrations of 
Table 2. Chemical quality of water

\begin{tabular}{|c|c|c|c|c|}
\hline \multirow[t]{2}{*}{ Parameters } & \multirow[t]{2}{*}{ Generic Standard } & \multicolumn{3}{|c|}{ Sampling Sites } \\
\hline & & Upstream & Midstream & Downstream \\
\hline Ammonia & 50.0 & 2.84 & 0.68 & 6.6 \\
\hline Phenol (mg/l) & 1.0 & $<0.01$ & 0.05 & 0.64 \\
\hline Cyanide (mg/l) & 0.2 & $<0.05$ & 0.06 & 0.08 \\
\hline Sulfide(mg/l) & 2.0 & 0.4 & 1.6 & 1.6 \\
\hline Oil \& grease $(\mathrm{mg} / \mathrm{l})$ & 10.0 & $<1.0$ & 19.0 & 16.0 \\
\hline Chloride (mg/l) & 600.0 & 25.7 & 25.7 & 50.5 \\
\hline Chromium(mg/l) & 0.1 & $<0.01$ & 0.04 & 0.02 \\
\hline $\mathrm{DO}(\mathrm{mg} / \mathrm{l})$ & NA & 3.8 & 2.9 & 0.0 \\
\hline $\mathrm{BOD}(\mathrm{mg} / \mathrm{l})$ & $30-100$ & 1.2 & 30.8 & 32.0 \\
\hline
\end{tabular}

NA- Not available

phenols in surface waters should not exceed $0.02 \mathrm{mg} / \mathrm{l}$ (Chapman 1996).

The cyanide was estimated between $0.05-0.08 \mathrm{mg} / \mathrm{l}$ in the wastewater of Sirsiya river. It is sourced from plating industries, burning coal and plastics, and effluent from publicly owned treatment works (POTW). The observed value is below the generic standard of $0.2 \mathrm{mg} / \mathrm{l}$. Strong sunlight and warm seasons favor biochemical oxidation causing a reduction in cyanide concentrations. Cyanides, especially ionic forms, are easily adsorbed by suspended matter and bottom sediments. The WHO has recommended a maximum concentration of $0.07 \mathrm{mg} / \mathrm{l}$ cyanide in drinking water, but many countries apply stricter standards of cyanide concentration both for drinking waters and natural water of importance for fisheries.

Sulfide in the wastewater ranged between 0.4 - 1.6mg/l. It was found below the generic standard recommended for the wastewater to discharge into surface water. The presence of high concentrations of surface indicates the presence of sewage in the industrial wastes. However, under aerobic conditions, the sulphide ion converts rapidly to sulphur and sulphate ions.

The oil and grease was found $<1.0,19$ and $16 \mathrm{mg} / \mathrm{l}$ for upstream, midstream and downstream respectively. It is an important parameter for water quality and safety. It can cause surface films and shoreline deposits leading to environmental degradation, and can induce human health risks when discharged in surface or ground waters. Additionally, oil and grease may interfere with aerobic and anaerobic biological processes and lead to decreased wastewater treatment efficiency. Regulatory bodies worldwide has set a limit of oil and grease in order to control the amount of oil and grease entering natural bodies of water or reservoirs through industrial discharges, and also to limit the amount present in drinking water.

The chloride in the effluent ranged between 25.7 - 50.5 $\mathrm{mg} / \mathrm{l}$. This value is less than the generic standard of $600 \mathrm{mg} / \mathrm{l}$ and also within WHO (2004) tolerance levels for discharge of wastewater into rivers or streams. In pristine freshwaters chloride concentrations are usually lower than $10 \mathrm{mg} / \mathrm{l}$ (Chapman 1996). The presence of high amounts of chloride and sulphate is responsible for the hardness and increases the degree of eutrophication (Kannan et al. 2005). Sodium chloride used as a dehydrating and antiseptic agent is the source of chloride (Mehdi 2005).

Chromium is toxic metal present in certain industrial wastewaters released from tanning, plating and coating industries. Chromium in the Sirsiya river was estimated at $<0.01,0.04$ and $0.02 \mathrm{mg} / \mathrm{l}$ from upstream, midstream and downstream respectively. It was found within the generic standard $(0.1 \mathrm{mg} / \mathrm{l})$. However, continuous discharge of chromium in low concentration has been reported to be toxic to aquatic life and can disrupt the aquatic food chain (Fent 2004).

The dissolved oxygen concentration was found in descending order from upstream to downstream. The highest concentration was detected at upstream $(38 \mathrm{mg} / \mathrm{l})$. It is a measure of degree of pollution by 
organic matter in water bodies. It is the destructive power of organic substance as well as the self purification capacity of the wastewater body. The effect of waste discharge on a surface water source is largely determined by the oxygen balance of the system and its presence is essential in maintaining biological life within a system (DFID 1999). Dissolved oxygen concentrations in unpolluted water normally range between 8 and $10 \mathrm{mg} / \mathrm{l}$ at $25^{\circ} \mathrm{C}$. Concentrations below $5 \mathrm{mg} / \mathrm{l}$ adversely affect aquatic life, and concentration below 2mg/l will cause fish kills (DFID 1999). The DO standard for sustaining fish and aquatic life is $4-5 \mathrm{mg} / \mathrm{l}$ (Rao 2005). The DO values are below the EPA standard of no less than $5.0 \mathrm{mg} / \mathrm{l}$ in order to maintain stable fish populations (Chapman 1996).

Both the BOD and COD tests are a measure of the relative oxygen-depletion effect of a waste contaminant. Both have been widely adopted as a measure of pollution effect. Biological oxygen demand (BOD) is the measure of the oxygen required by microorganisms whilst breaking down organic matter. While chemical oxygen demand (COD) is the measure of amount of oxygen required by both potassium dichromate and concentrated sulphuric acid to breakdown both organic and inorganic matters.

The BOD of the water bodies varied from 1.2 - $32 \mathrm{mg} / \mathrm{l}$ and COD varied from 7.0 - $140 \mathrm{mg} / \mathrm{l}$. The lower value of BOD and COD at upstream is indicator of water being very less polluted. However, the value at midstream and downstream clearly indicated the continuous addition both organic and inorganic pollutants into the river. The observed values were found less than the generic standard of $30-100 \mathrm{mg} / \mathrm{l}$ for BOD and 250mg/l for COD. Though the values are below the standard, it might have some effect in long term. In the same way, present observation agrees with the previous works of Fatoki et al. (2003) and Morrison et al. (2001). The study revealed that the continuous discharge of effluent negatively impact the receiving water bodies and also effects to the aquatic lives.

Thus, the present study was carried out to evaluate the impact of industrial effluent on water quality of Sirsiya river. It was found that all the parameters were within the generic standard except for oil and grease. However, it does not mean that the water is free from pollution. The dilution of water by tributaries of Sirsiya river may be the reason for lower concentration pollutants. The physical appearance itself is the proof of heavy contamination of river water and therefore the effluent could pose significant health and environmental risk to rural communities.

\section{Acknowledgements}

I express my sincere gratitude to Mr. Surendra Parajuli, Officer at Water Engineering and Training Center Pvt. Ltd for his support in field and laboratory works. The financial support provided by the Himalayan Alliance for Climate Change (HIMCCA) to conduct this study is highly acknowledged.

\section{References}

APHA. 2005. Standard methods for the examination of water and waste water, $21^{\text {th }}$ Edition. American Public Health Association, American Water Works Association, Water Pollution Control Federation. Published by the American Public Health Association, Washington DC, USA.

Chapman, D.1996. Water quality assessments: A guide to the use of biota, sediments and water in environmental monitoring 2nd. Ed. UNESCO, World Health Organization, United Nations Environment Programme, London, $92 \mathrm{p}$.

DFID. 1999. A simple methodology for water quality monitoring (Eds. G. R. Pearce, M. R. Chaudhry and S. Ghulum), Department for International Development Wallingford, $16 \mathrm{pp}$.

Fatoki, S.O., P. Gogwana and A.O. Ogunfowokan. 2003. Pollution assessment in the Keiskamma River and in the impoundment downstream. Water SA. 29 (3): 183187.

Fent, K. 2004. Ecotoxicological effect at contaminated sites. Toxicology 205: 223-240.

Jaji, M.O., O. Bamgbose, O.O. Odukoya and T.A. Arowlo. 2007. Water quality assessment of Ogun river, south west Nigeria. Environ. Monit. Assess. 133 (1-3): 447482.

Kannan, V., R. Ramesh, and C. Sasikumar, 2005. Study on ground water characteristics and the effects of discharged effluents from textile units at Karur District. Journal of Environmental Biology 26(2): 269-272.

Mara, D. and S. Cairncross. 1989. Guidelines for the safe use of wastewater and excreta in agriculture and aquaculture. World Health Organization and United Nations Environment Program.

McCulloch, W.L., Jr., W.L Goodfellow and J.A. Black. 1993. Characterization, identification and confirmation of total dissolved solids as effluent toxicants. Environ. Toxicol. Risk Assess. 2: 213-227.

Mehdi, A. 2005. Effect of waste water disposal and extent of industrial pollution in and around Kanpur, 
Binod P. Shah \& Bhoj R. Pant/Water Quality Assessment.

Uttarpradesh, India. Bulletin of Engineering Geology and the Environment 60: 31-35.

Morrison, G., O.S. Fatoki, L. Persson and A. Ekberg. 2001. Assessment of the impact of point source pollution from the Keiskammahoek sewage treatment Plant on the Keiskamma river, Water SA. 27 (4): 475-480.

Rao, P. V. 2005. Textbook of environmental engineering. Eastern Economy Ed., Prentice-Hall of India Private Limited, New Delhi. 280p.
Somnath, V. 2003 Impact of tannery effluent on bioenergetics of fishes, Journal of Ecotoxicology and Environmental Monitoring 13(3): 161-173.

Train, R.E. 1979. Quality criteria for water. Castle House Publications Ltd., London.

World Health Organization. 2004. Guidelines for drinking water quality. Third Edition, Vol. 1. Recommendation WHO: Geneva, Switzerland 515. 426 p. 
Nepal Journal of Science and Technology Vol. 13 No. 2 (2012) 141-146 